\title{
Application of supply chains management in construction project: a review in the compatibility between the procurements and implementation process
}

\section{Yazan Dannoun}

Civil Engineering Department, Near East University, Nicosia, Via Mersin 10, Turkey

\section{ARTICLE INFO}

ARTICLE HISTORY:

Received: 15 December 2021

Revised: 21 December 2021

Accepted: 15 January 2022

Published: 31 January 2022

KEYWORDS:

Supply chain management, procurement, construction industry

\begin{abstract}
A B S T R A C T
In response to rising public demand for corporate, industrial, and private expansion, as well as lowcost residential construction, Turkey's development sector has burst in recent decades, and the Turkish government has placed a significant focus on industry. As a result, a methodical approach is required to cut down on money, time and waste. In the building business, dealing with the problem appears to be critical. It is debatable whether Supply Chain Management), a concept that first appeared and progressed in the automobile manufacturing industry, where it has found success, is one of the reliable practices that could primarily be the remedy for the construction industry's dispute, time, and cost excess. According to the construction sector, supply chain management has a lot of promise for increasing project productivity. This method, however, has not been effective in many nations, notably in Turkey. The major purpose of this study is to evaluate and examine the SCM implementation process in the Turkish construction sector based on previous studies, with an emphasis on efficient building procurement and supply. This will be accomplished by a rigorous literature analysis that will distinguish the industry's flaws and strengths. The benefits of SCM application in the construction sector, hurdles to successful SCM implementation in the purchase and delivery of building materials, and elements that reinforce the implementation will all be part of our study's model framework.
\end{abstract}

\section{INTRODUCTION}

Construction creates the structures that house a wide range of human activities, as well as the infrastructure that connects these facilities into a sophisticated network (Picchi, 2002). There are other additional characteristics that may be used to split the building business into segments or sectors. The construction industry is a commercial and economic sector that deals with land preparation, structure building, real estate development, and facility restoration and maintenance (Halpin et al., 2010).

The industry of construction is extremely fragmented and consists of a huge number of sub-industries. Because of the diverse structure of the construction business, there is a lack of adequate communication and difficulty sustaining connections among construction industry members (contractors, subcontractors, suppliers, customers, and so on) along the supply chain (Ahmed et al., 2002). Smallscale initiatives to megaprojects are all part of the construction process. Construction starts with project planning, design, and finance and continues until the project is completed and ready for use. It also includes infrastructure design, planning, budgeting, building's material transportation and availability, as well as construction site safety, logistics, execution, and maintenance (Zçelebi, 2011).

Surprisingly, a general contractor's main responsibility under a contract agreement with the customer is building. According to Koskela (1992), construction differs significantly from other sectors in terms of projects, manufacturing sites, temporary regulation, and multiorganizational participation. Each customer has distinct requirements or priorities. The climatic, ground, and environmental factors at each building site are unique. The architectural designs and solutions provide the distinctive traits or originality of any building or structure. The manufacturing site is limited to a certain area and is affected by physical elements such as weather and land characteristics (Vrijhoef \& Koskela, 2005). 
In this study, the application of CSCM in Turkish construction industry, merits, demerits and barriers Turkey construction industry and its CSCM applications,

barrier, will be examined in depth in this research, and a recommendation will be made for the building of a successful future Turkey CSCM model, process, and method.

\subsection{Turkish construction industry}

Turkey is a significant player in the worldwide building market and industry. After the Second World War ended in 1945, the Turkish construction sector began to grow. Because of the United States government's 'Marshall Aids' money, Turkey's building industry grew considerably between 1950 and 1970. Turkey's construction industry is largely non-unionized. The Ministry of Public Works and Resettlement is the largest owner of all. Airport, Port, Railroad, Highways, Technical Research and application, Catastrophe Precautions and Construction Works are the six general directorates (Alptekin, 2017).

Informative flows, machinery, material and labor are all strategic considerations in the building sector. A good performance in the major industries might boost profit margins in the construction industry, as well as offer value and benefit to the economy. In this case, supply chain management (SCM) might be a very beneficial tool for construction companies. This is especially appealing when we consider how fragmented the construction industry is, and how good outcomes need strong chain integration, coordination, and management from suppliers to end clients (Koçtaş \& Tek, 2013).

\section{SUPPLY CHAIN MANAGEMENT (SCM)}

End users and suppliers who create and sell products, services, and information make up the supply chain (SC), which is made up of a network of major commercial facilities and operations. All business inventories, such as planning, marketing, distribution, manufacturing, purchasing, and organizations, as well as a supply chain, used to function independently in order to implement SCM principles. Many industries have looked into, identified, and recognized the value of harnessing all of the elements along the SC. Cost savings, enhanced change detection, greater customer value and service quality, and improved decisionmaking are all benefits of the SC application (Vrijhoef \& Koskela, 2000; London \& Kenley, 2001; Cheng et al., 2010). SCM is a fundamental notion that stems from the need to track and manage logistics in a busy manufacturing. It is the technique to management through which the initiative controls, runs, and oversees the global connectedness of suppliers, circulation hubs, warehouses, and traders through which resources are distributed, processed, and traded, transformed, and supplied for client use. The concept of SCM in manufacturing as it applies to construction is depicted in Fig. 1.. Procurement of products and services, as well as other procurement-related responsibilities, occur throughout each step of a construction project in the construction business (Chirag et al., 2015). Resources such as materials, machinery, personnel, and other services may not always be provided on time, in the proper amount, or at the suitable quality and rate due to unforeseen problems and several stages involved in the building program.

To completely control, monitor, regulate, optimize all logistics-related operations and sustain, a strategic management concept such as SCM is required (Zçelebi, 2001). SCM has applications, advantages, implementation difficulties, and problems in the literature, particularly those connected to building operations (Ahmed et al., 2002; Aloini et al., 2012; Gosling et al., 2013; Ebraim et al., 2015; Koçtaş \& Tek, 2013).

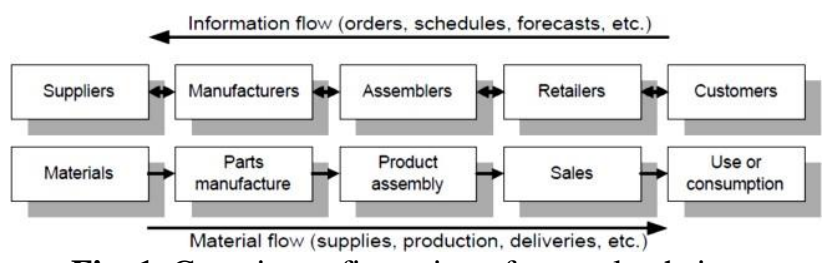

Fig. 1. Generic configuration of a supply chain (Vrijhoef \& Koskela, 1999).

\section{SUPPLY CHAIN MANAGEMENT (SCM) IN CONSTRUCTION}

Construction supply chain management is another name for supply chain management in the construction industry (CSCM). CSCM is a specific component of SCM for construction operations with distinct features. SCM in construction (CSCM) refers to the network of activities and facilities that give economic and customer value to the design and functions of contract management, development, service procurement of material, materials manufacturing and delivery, facilities management, and design (Love et al., 2002). Every construction project is unique, and each construction project requires a distinct product. CSCM is effectively make-to-order SC (Vrijhoef \& Koskela, 2000). By implementing contemporary, comprehensive, and integrative SCM systems, CSCM overcomes fragmentation issues in the conventional construction sector and its processes (particularly procurement) (Pryke, 2009).

In addition, the CSCM used data and transactions as a resource tool to help eliminate unnecessary labor division, decrease costs, improve dependability and speed up facility building (Cheng et al., 2010; O'Brien et al., 2008). CSCM also aids in the creation of an enabling work environment that improves collaboration, coordination, commitment and cohesion among all construction stakeholders (Meng, 2010). CSCM is well-suited to logistics costs, inventory to 
guarantee that supplies, controlling lead time, machineries move freely to the job site and personnel, preventing disruptions to the workflow. (Vrijhoef \& Koskela, 2000; O'Brien et al., 2008) state that CSCM plays a significant role in global sourcing of assembly and materials, labor, and offshore value-added activity. By increasing visibility, training, awareness and transparency in construction procedures, activities and operations, CSCM removes uncertainty issues (Young et al., 2011).

\section{ADVANTAGES OF SUPPLY CHAIN MANAGEMENT (SCM)}

When construction businesses use traditional procurement methods, according to Chirag and Bhavin (2015), there is no significant reason to act in the client's best interests. Only that the specified products or services be delivered as cheaply as feasible to the provider. In addition, the client's primary concern is the lowest price as compared to set prices. SC and innovation in operations, technology, and product development are critical components of business excellence (Ulusoy, 2003). Individual construction enterprises in the state of South Carolina can profit from SCM in the following ways:

- An incentive to be more confident in forecasting future turnover,

- SCM provides direction and promotes the establishment of a constant supply and demand,

- SCM fosters a positive working connection and helps to expand the business as a whole,

- An incentive to provide the client with more valuable material,

- The incentive system for reducing waste in the SC process,

- The motivation to do more repeat business with happy customers,

- An incentive to cut expenses and increase production cost certainty.

\section{DISADVANTAGES OF SUPPLY CHAIN MANAGEMENT (SCM)}

The following are some of the general concerns with SCM (Akintoye et al., 2000; Vrijhoef et al., 2001; Dianty et al., 2001):

- A scarcity of suitable information technology,

- Uncertain strategic advantages,

- Having a weak organizational framework to back you up,

- Inadequate grasp of supply chain management,

- Partners' lack of commitment,
Ineffective methods for assessing the performance of various parties,

- Labors, contractors and subcontractors performing subpar work,

- Insufficient SCM input, primarily due to inadequate planning and control,

- A lack of communication and exchange of information,

- Errors in design and poor materials quality.

\section{CONCLUSIONS}

In fact, the advantages of SCM may not be as straightforward as they look, because numerous barriers to adoption coexist with the advantages (Akintoye et al., 2000; Vrijhoef et al., 2001; Dianty et al., 2001). The following are some of the hindrances to SCM adoption that have been identified:

- Internal processes are not integrated; there is a lack of confidence both within and outside the firm; and there is organizational opposition to the notion of supply chain management,

- Inadequate institutionalization of the organization,

- Failure to create monitoring procedures for the alliance,

- There is a lack of instruction on how to form partnerships with supply chain partners,

- A scarcity of suitable information technology,

- Uncertain strategic advantages,

- Partners' lack of commitment,

- The SCM system is not supported by a sufficient organizational structure,

- A lack of knowledge of the SCM idea,

- A lack of commitment from upper management.

\section{CONFLICT OF INTEREST STATEMENT}

The author declares that there is no conflict of interest.

\section{REFERENCES}

[1] Ahmed, S. M., Azhar, S., \& Ahmad, I. (2002). Supply chain management in construction: Scope, benefits and barriers. Delhi Business Review, 3(1), 1-6.

[2] Akintoye, A., McIntosh, G., \& Fitzgerald, E. (2000). A survey of supply chain collaboration and management in the UK construction industry. European Journal of Purchasing \& Supply Management 6(3-4),159-168.

[3] Albatanony, M. A., \& El-Shafie, M. K. (2011). Workrelated health effects among wastewater treatment plants workers. Int J Occup Environ Med (The IJOEM), 2(4 October).

[4] Alptekin, G. Ö. (2017). Comparison in terms of delays 
in the construction contracts used in Turkey. GRADEVINAR, 69(6), 489-496.

[5] Cheng, J. C., Law, K. H., Bjornsson, H., Jones, A., \& Sriram, R. D. (2010). Modeling and monitoring of construction supply chains. Advanced Engineering Informatics, 24(4), 435-455.

[6] Halpin, Daniel W.; Senior, Bolivar A. (2010), Construction Management (4 ed.), Hoboken, NJ: John Wiley \& Sons, p. 9, ISBN 9780470447239, retrieved May 16, 2015.

[7] Koçtaş, Ö., \& Tek, Ö. B. (2013, November). Construction supply chains: a proposal to develop a new conceptual model. In International logistics and supply chain congress.

[8] Koskela, L. (1992). Application of the new production philosophy to construction (Vol. 72). Stanford: Stanford university.

[9] Koskela, L. (2000). An exploration towards a production theory and its application to construction. VTT Technical Research Centre of Finland.

[10] Love, P. E., Irani, Z., \& Edwards, D. J. (2004). A seamless supply chain management model for construction. Supply chain management: an international journal, 9(1), 43-56.

[11] Meng, X., Sun, M., \& Jones, M. (2011). Maturity model for supply chain relationships in construction. Journal of Management in Engineering, 27(2), 97-105.

[12] O’Brien, W.J, Formoso, C. T., Ruben, V., \& London, K. (2008). Construction supply chain management handbook, CRC Press. https://doi.org/10.1201/9781420047462

[13] Patel, C., Bhavin, D., \& Parsania, P. H. (2015). Effect of temperature and solvents on ultrasonic velocity and thermodynamic parameters of cyclohexane-1, 1-diylbis (2-methyl-4, 1-phenylene) dibenzoate solutions. J. Ind. Chem. Soc, 92, 1-13.

[14] Picchi, F. A., 2002, "System view of lean construction application opportunities", (IGLC-10), Gramado, Brazil.

[15] Pryke, S. (Ed.). (2009). Construction supply chain management: concepts and case studies (Vol. 3). John Wiley \& Sons.

[16] Rao, Y. A., Kumar, N. S., Amaresh, H. S., \& Chirag, H. V. (2015, November). Real-time speed estimation of vehicles from uncalibrated view-independent traffic cameras. In TENCON 2015-2015 IEEE Region 10 Conference (pp. 1-6). IEEE.

[17] Ulusoy, G., (2003). Competitive manufacturing strategies for the manufacturing industries in Turkey. 1st Joint EurOMA \& POMS Conference (EUROMAPOMS). European Operations Management Association. Cernobbio, Lake Como, Italy, 313-322.

[18] Vrihjhoef, R., \& Koskela, L. (1999). Roles of supply chain management in construction. In Proceedings of IGLC 7th Annual Conference, Berkeley, CA, 133-146. http://cic.vtt.fi/lean/conferences.htm
[19] Vrijhoef, R., \& Koskela, L. (2000). The four roles of supply chain management in construction. European journal of purchasing \& supply management 6(3), 169178.

[20] Vrijhoef, R., \& de Ridder, H. (2005). Supply chain integration for achieving best value for construction clients: client-driven versus supplier driven integration. Proceedings QUT Research Week, 4-6.

[21] Young, D. A., Haas, C. T., Goodrum, P., \& Caldas, C. (2011). Improving construction supply network visibility by using automated materials locating and tracking technology. Journal of Construction Engineering and Management, 137(11), 976-984.

[22] Zhang, J. P., \& Hu, Z. Z. (2011). BIM-and 4D-based integrated solution of analysis and management for conflicts and structural safety problems during construction: 1. Principles and methodologies. Automation in construction, 20(2), 155-166. 